\title{
Potential Role of PDGFR $\beta$-Associated THBS4 in Colorectal Cancer Development
}

\author{
Min Seob Kim ${ }^{1}{ }^{\mathbb{D}}$, Hyun Seok Choi ${ }^{1}$, Moxin Wu ${ }^{1} \mathbb{D}$, JiYeon Myung ${ }^{1}$, Eui Joong Kim ${ }^{2}$,

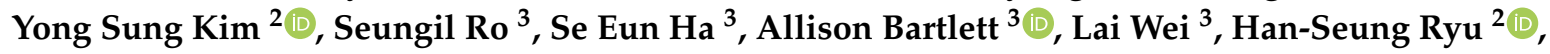 \\ Suck Chei Choi ${ }^{2}$, Won Cheol Park ${ }^{4}$, Keun Young Kim ${ }^{4}$ ) and Moon Young Lee ${ }^{1, *}$ \\ 1 Department of Physiology, Digestive Disease Research Institute, and Institute of Wonkwang Medical Science, \\ School of Medicine, Wonkwang University, Iksan 54538, Korea; kmsnim00@naver.com (M.S.K.); \\ wlsahrch006@naver.com (H.S.C.); wumoxinsbsb@163.com (M.W.); mjy1229@naver.com (J.M.) \\ 2 Department of Gastroenterology, Digestive Disease Research Institute, School of Medicine, \\ Wonkwang University, Iksan 54538, Korea; blueliebe98@naver.com (E.J.K.); wms89@hanmail.net (Y.S.K.); \\ hanseung43@naver.com (H.-S.R.); medcsc@wku.ac.kr (S.C.C.) \\ 3 Department of Physiology and Cell Biology, University of Nevada School of Medicine, Reno, NV 89557, USA; \\ sro@medicine.nevada.edu (S.R.); seeunh@med.unr.edu (S.E.H.); allisonbartlett@nevada.unr.edu (A.B.); \\ laiw@med.unr.edu (L.W.) \\ 4 Department of Surgery, Digestive Disease Research Institute, School of Medicine, Wonkwang University, \\ Iksan 54538, Korea; parkwc@wonkwang.ac.kr (W.C.P.); saint9898@naver.com (K.Y.K.) \\ * Correspondence: lmy6774@wku.ac.kr; Tel.: +82-10-9437-6774
}

Received: 9 July 2020; Accepted: 31 August 2020; Published: 6 September 2020

Simple Summary: We found increased levels of THBS4 and PDGFRb in tumor tissues compared to normal tissues of colon cancer patients. The relationship and the cause of the increase in these proteins had to be determined. Therefore, we performed several experiments and confirmed that excessive PDGFRb stimulation induces the THBS4 secretion through the intracellular $\mathrm{Ca}^{2+}$ signaling proteins. Our data show the possibility of post-translational modification of THBS4 by PDGFRb stimulation as there was no significant change in the THBS4 mRNA.

Abstract: Colorectal cancer is a significant cause of death since it frequently metastasizes to several organs such as the lung or liver. Tumor development is affected by various factors, including a tumor microenvironment, which may be an essential factor that leads to tumor growth, proliferation, invasion, and metastasis. In the tumor microenvironment, abnormal changes in various growth factors, enzymes, and cytokines can wield a strong influence on cancer. Thrombospondin-4 (THBS4), which is an extracellular matrix protein, also plays essential roles in the tumor microenvironment and mediates angiogenesis by transforming growth factor- $\beta$ (TGF $\beta$ ) signaling. Platelet-derived growth factor receptor $\beta$ (PDGFR $\beta$ ), which is a receptor tyrosine kinase and is also a downstream signal of TGF $\beta$, is associated with invasion and metastasis in colorectal cancer. We identified that PDGFR $\beta$ and THBS4 are overexpressed in tumor tissues of colorectal cancer patients, and that PDGF-D expression increased after TGF $\beta$ treatment in the colon cancer cell line DLD-1. TGF $\beta$ and PDGF-D increased cellular THBS4 protein levels and secretion but did not increase THBS4 mRNA levels. This response was further confirmed by the inositol 1,4,5-triphosphate receptor (IP3R) and stromal interaction molecule 1 (STIM1) blockade as well as the PDGFR $\beta$ blockade. We propose that the PDGFR $\beta$ signal leads to a modification of the incomplete form of THBS4 to its complete form through IP3R, STIM1, and $\mathrm{Ca}^{2+}$-signal proteins, which further induces THBS4 secretion. Additionally, we identified that DLD-1 cell-conditioned medium stimulated with PDGF-D promotes adhesion, migration, and proliferation of colon myofibroblast CCD-18co cells, and this effect was intensified in the presence of thrombin. These findings suggest that excessive PDGFR $\beta$ signaling due to increased TGF $\beta$ and PDGF-D in colorectal tumors leads to over-secretion of THBS4 and proliferative tumor development. 
Keywords: THBS4; PDGFR $\beta ; \mathrm{Ca}^{2+}$; colorectal cancer

\section{Introduction}

Colorectal cancer (CRC) is one of the most prevalent cancers in the world and is a major cause of cancer-related deaths. During the progression of colorectal adenocarcinomas, gastrointestinal epithelial cells acquire subsequent genetic changes and mutations in specific oncogenic or tumor suppressor genes, which leads to CRC onset, progression, and metastasis [1].

The tumor microenvironment is a tumor pathology-related environment composed of tumor cells, stromal cells, cytokines, immune cells, pericytes, and other components [2,3]. In the tumor microenvironment, several growth factors, proteolytic enzymes, and inflammatory factors act on the surface of tumor cells, which have important effects on cell proliferation, metastasis, and differentiation [4,5]. Thrombospondin-4 (THBS4) is a secreted extracellular matrix protein and one of five members of the thrombospondin protein family. These thrombospondin family members are $\mathrm{Ca}^{2+}$-binding extracellular glycoproteins that share a highly conserved C-terminal region but have unique $\mathrm{N}$-terminal domains that play fundamental roles in wound healing and tissue repair [6-9]. THBS4 is part of a subgroup B of the thrombospondin family members, including THBS3 and 5, and is known to affect intracellular migration, adhesion, and attachment as well as proliferation under varying conditions [10-13]. There is increasing data to support the role of THBS4 in cancer biology, especially in gastrointestinal and prostate tumors [14,15]. Additionally, it has been suggested that, because of rare genomic alterations in the THBS4 genes, a remarkable activation of THBS4 expression in tumors is most likely regulated through the interaction of invading tumor cells with stromal fibroblasts in the local microenvironment [16].

There is a report that platelet-derived growth factor receptor (PDGFR) and THBS4 may be involved in the same pathway [17]. Platelet-derived growth factor receptor (PDGFR) stimulation induces the activation of intracellular signaling pathways that can promote cell migration, invasion, survival, and proliferation [18,19]. PDGFR signaling affects the aggressive behavior of other epithelial tumors such as in breast, liver, and pancreatic cancers, as PDGFR overexpression is associated with advanced-stage cancer and poor prognosis in all tumor types [20-22]. In CRC, PDGFR seems to be primarily expressed by stromal cells and pericytes [23,24]. Platelet-derived growth factor receptor $\beta$ (PDGFR $\beta$ ), which is a member of the PDGFR family, can also be expressed and induce primary signaling in colorectal tumor cells $[25,26]$. There are four structurally similar proteins within the PDGF family, namely PDGF-A, PDGF-B, PDGF-C, and PDGF-D, which bind with varying affinities to receptor tyrosine kinase (RTK) receptor units PDGFR $\alpha$ and PDGFR $\beta$ [27,28]. Notably, PDGF-D leads to phosphorylation of PDGFR $\beta$, promotes CRC cell migration, invasion, and proliferation, and is highly expressed in human colon cancer DLD-1 cells [29,30].

Several studies have reported that PDGFR $\beta$ or THBS4 are associated with transforming growth factor- $\beta$ (TGF $\beta$ ) [31-33]. Inhibition of TGF $\beta$ signaling in tumor cells significantly decreases PDGFR $\beta$ expression and PDGF-stimulated tumor cell invasion, which indicates the possibility of downstream TGF $\beta$ signaling [33]. In several studies, TGF $\beta-1$, which is an analogous member of the TGF $\beta$ cytokine family, promotes angiogenesis by altering the extracellular matrix (ECM) composition through THBS4 upregulation [31,32]. The ability of tumors to manipulate the immune system and allow for uninhibited cell proliferation is partially due to the exploitation of the regulatory cytokine TGF $\beta$ signaling pathway. TGF $\beta$ is an integral protein involved in cell immune regulation, cell invasion, and microenvironment restructuring [34-36].

Previous studies show that the phosphorylation of PDGFR activates a signaling cascade hydrolyzing inositol 1,4,5-triphosphate receptor (IP3R), among other proteins, to induce $\mathrm{Ca}^{2+}$ release, which leads to a depletion of $\mathrm{Ca}^{2+}$ stores within the endoplasmic reticulum (ER) as well as $\mathrm{Ca}^{2+}$ re-entering the cell [37-40]. The IP3R and the stromal interaction molecule 1 (STIM1) proteins are 
localized to intracellular membranes, such as the ER, and control the influx and diffusion of $\mathrm{Ca}^{2+}$ into the cell and cytoplasm. $\mathrm{Ca}^{2+}$ is imperative for cellular functions such as intracellular signaling, and IP3R and STIM1 are integral components of the regulatory mechanisms in $\mathrm{Ca}^{2+}$ signaling within the cell. Remodeling of $\mathrm{Ca}^{2+}$ homeostasis in CRC contributes to proliferation, invasion, and survival [41-43]. Based on the studies described above, we hypothesized that increased PDGFR $\beta$ induces remodeling of $\mathrm{Ca}^{2+}$ homeostasis, and, thereby, increases THBS4 secretion.

In this study, using cell assay techniques, transcript and protein analyses in colon cancer patient tissue, and the cell line, we show that PDGFR $\beta$ stimulation by TGF $\beta$ and PDGF-D increases the THBS4 secretion via IP3R and STIM1 in colorectal cancer.

\section{Results}

\subsection{Expression of THBS4 and PDGFR $\beta$ in Colorectal Cancer}

There is increasing evidence that THBS4 and PDGFR $\beta$ are associated with tumor development [10-13,16,20-26]. To investigate the association between these two proteins in the tumor, we performed co-immunofluorescence and Western blot analyses for THBS4 and PDGFR $\beta$ in tumor tissues of patients with CRC. Compared to normal tissues, elevated levels of PDGFR $\beta$ and THBS4 were found in tumor tissues, which confirms our hypothesis that these two proteins are significantly associated with tumor development in CRC (Figure 1 and Figure S1).

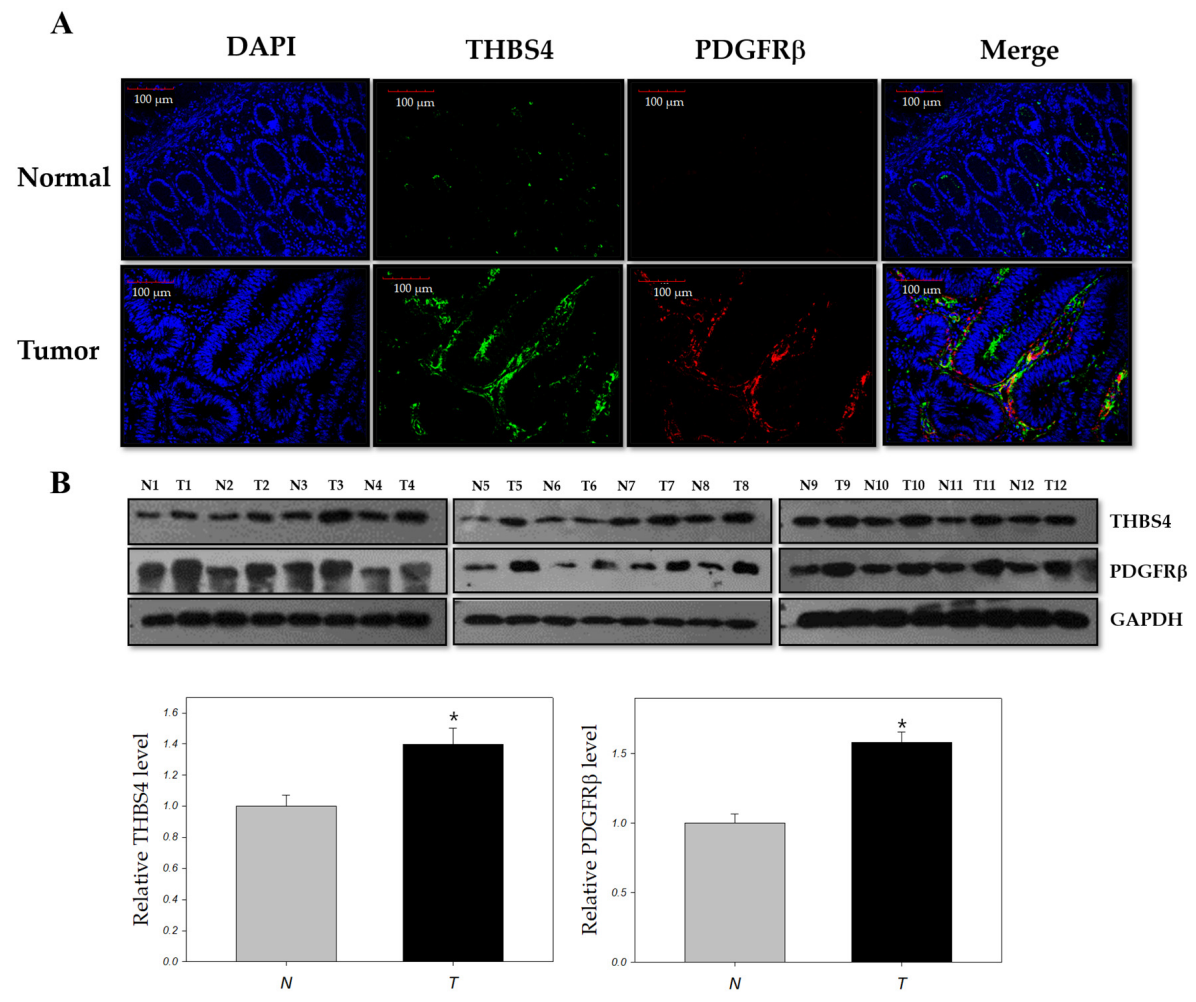

Figure 1. Co-immunofluorescence and immunoblots for Thrombospondin-4 (THBS4) and Platelet-derived growth factor receptor $\beta$ (PDGFR $\beta$ ) in normal and tumor tissues of colon cancer patients. (A) Immunofluorescence with an anti-THBS4 antibody (green) and anti-PDGFR $\beta$ antibody (red) on normal $(\mathrm{N})$ and tumor $(\mathrm{T})$ tissues of colon cancer patients. Scale bars $=100 \mu \mathrm{m}$. (B) Western blot with anti-THBS4 and anti-PDGFR $\beta$ antibodies on normal and tumor tissues of colon cancer patients. ${ }^{*} p<0.05$, compared with normal tissue, $t$-test. 


\subsection{TGF $\beta$ Stimulates Increased $m R N A$ and Protein Expression of PDGF-D}

The role of TGF $\beta$ in CRC is also of interest, as it has been shown to be an upstream signal of PDGFR $\beta$ in tumor cells [33], and is involved in angiogenesis through THBS4 [31,32]. Therefore, to investigate the effects of TGF $\beta$ on PDGFR $\beta$ and THBS4 overexpression in CRC, we examined the mRNA levels of PDGFR $\beta$ and THBS4 after treatment with TGF $\beta$ for $12 \mathrm{~h}$ in DLD-1 cells, which is a colon cancer cell line. Neither THBS4 nor PDGFR $\beta$ mRNA levels were significantly altered in response to TGF $\beta$ treatment (Figure 2A). However, PDGF-D mRNA levels, among PDGFR ligands (PDGF-A, PDGF-B, PDGF-C, and PDGF-D), were significantly increased by TGF $\beta$ (Figure 2B). The protein expression level of PDGF-D also increased, and a PDGF-D receptor, [44] PDGFR $\beta$, was activated in the presence of TGF $\beta$ (Figure 2C). These results were similar in another CRC cell line HCT-116 (Figure S2).

A

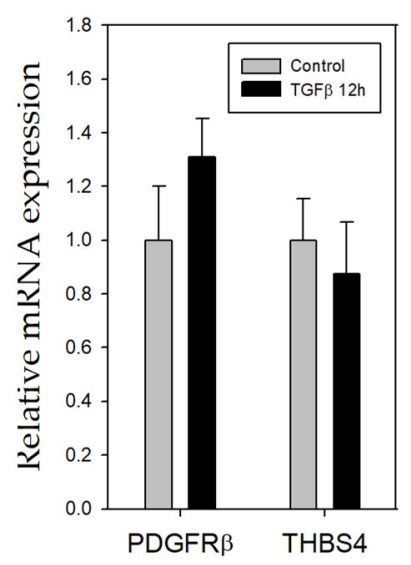

B

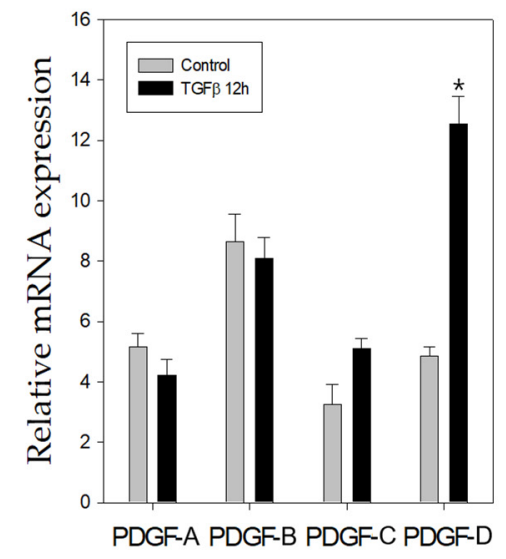

C
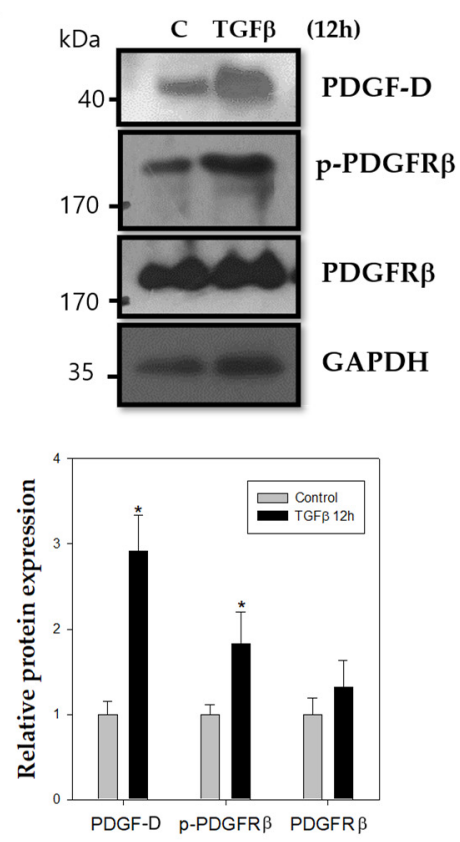

Figure 2. Effect of TGF $\beta$ on mRNA levels of THBS4, PDGFR $\beta$, and PDGFR $\beta$ ligands. Relative mRNA expression levels as determined with real-time polymerase chain reaction (PCR) for (A) PDGFR $\beta$, THBS4, (B) PDGF-A, PDGF-B, PDGF-C, and PDGF-D of DLD-1 cells cultured in the presence (TGF $\beta 10 \mathrm{mM}$ ) or absence (control) of TGF $\beta$ for $12 \mathrm{~h}$. (C) Western blot with anti-PDGF-D, p-PDGFR $\beta$, and PDGFR $\beta$ antibodies in DLD- 1 cells cultured in the presence (TGF $\beta 10 \mu \mathrm{M}$ ) or absence (control) of TGF $\beta$ for $12 \mathrm{~h}$. Three independent experiments were performed in duplicate. ${ }^{*} p<0.05$ when compared with the control $t$-test.

\subsection{TGF $\beta$ and PDGF-D Influence the Post-Translational Modification and Secretion of THBS4}

Based on the above results, we hypothesized that PDGF-D would act as a downstream signal for TGF $\beta$ on THBS4 upregulation. To examine how TGF $\beta$ and its downstream protein PDGF-D affects THBS4 protein levels and secretion, since TGF $\beta$ did not significantly alter THBS4 mRNA, DLD- 1 cells were treated with TGF $\beta$ at 1,2, 5, 10, and $20 \mu \mathrm{M}$ for $20 \mathrm{~h}$ or PDGF-D for $8 \mathrm{~h}$. Cell lysates and media containing THBS4 were considered to be intracellular and extracellular, respectively. Increased levels of THBS4 were found in the cell lysate and culture medium in the presence of TGF $\beta$ or PDGF-D in a dose-dependent manner (Figure 3A). However, PDGF-D did not significantly alter THBS4 mRNA levels like TGF $\beta$ (Figure 3B). Thus, these data suggest that TGF $\beta$ and PDGF-D in DLD-1 cells might be involved in the post-translational modification and secretion of THBS4, rather than conferring protein production through THBS4 mRNA expression. 
A
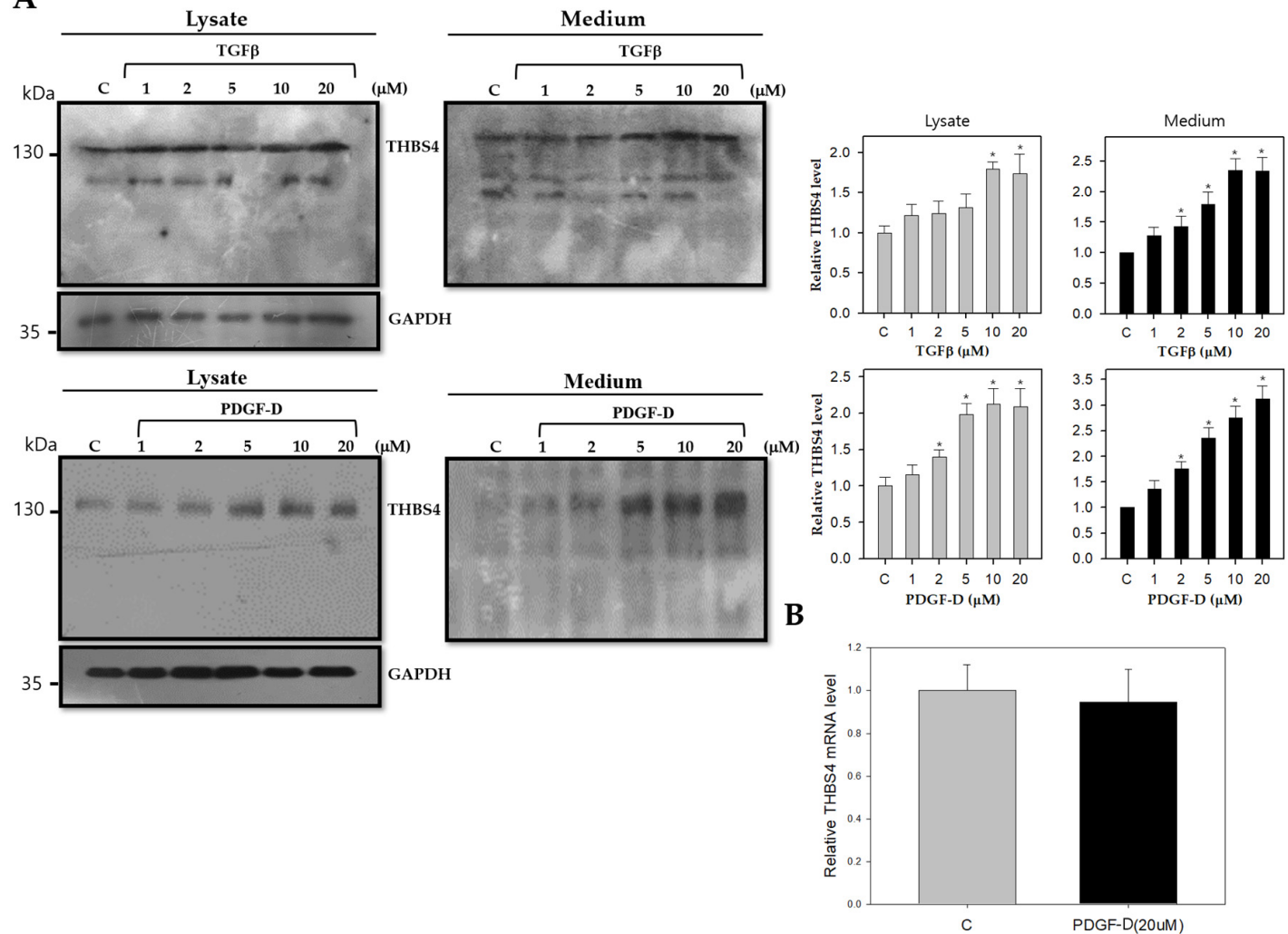

Figure 3. Effect of TGF $\beta$ or PDGF-D on THBS4 of lysate and cultured medium of DLD-1 cells. (A) Western blot with anti-THBS4 antibody in whole cell lysate (left panel) or cultured medium (right panel) of DLD-1 cells cultured in the presence of TGF $\beta(1,2,5,10$ and $20 \mu \mathrm{M})$ for $20 \mathrm{~h}$ or PDGF-D $(1,2,5,10$, and $20 \mu \mathrm{M})$ for $8 \mathrm{~h}$. (B) Relative mRNA expression levels as determined with real-time polymerase chain reaction (PCR) for THBS4 of DLD-1 cells cultured in the presence (black) or absence (gray) of PDGF-D $(20 \mu \mathrm{M})$ for $8 \mathrm{~h}$. Three independent experiments were performed in duplicate. * $p<0.05$ when compared with the control $t$-test.

\subsection{Knockdown of $\mathrm{Ca}^{2+}$ Signaling Proteins Decreases THBS4 Secretion Even on PDGF-D}

To investigate the effects of PDGF-D on the secretion of THBS4, we treated DLD-1 cells with the PDGFR $\beta$ inhibitor, imatinib, to identify changes in THBS4 secretion. By inhibiting PDGFR $\beta$, PDGF-D signaling was also subsequently inhibited. DLD-1 cells were treated with imatinib at $0.2,0.5,1,2$, and $5 \mu \mathrm{M}$, respectively, for $16 \mathrm{~h}$, including an additional treatment with PDGF-D for $8 \mathrm{~h}$. In both the cell lysate and culture medium, there was decreased expression of THBS4 in a dose-dependent manner, which indicates the essential role of PDGF-D signaling on THBS4 expression (Figure 4A, upper panel). Previous literature shows a $\mathrm{Ca}^{2+}$ binding domain in the C-terminal region of THBS4 [6-9]. Therefore, we also suspected that the $\mathrm{Ca}^{2+}$ signaling proteins, IP3R and STIM1, might be involved in THBS4 activity. To investigate this idea, we treated DLD-1 cells with the IP3R inhibitor, 2-APB, and a STIM1 inhibitor, ML-9, at concentrations of 5, 10, 20, 50, and $100 \mu \mathrm{M}$ for $16 \mathrm{~h}$. We also administered an additional treatment with PDGF-D for $8 \mathrm{~h}$. Similar to PDGFR $\beta$ inhibition, we found decreased expression of THBS4 in the culture medium under 2-APB or ML-9 (Figure 4A, middle and lower panel). Despite rescue treatment with PDGF-D in siIP3R-transfected and siSTIM1-transfected DLD-1 cells, THBS4 levels remained at reduced levels in the lysate and cultured medium (Figure 4B). However, even with the treatment of inhibitors such as imatinib, 2-APB, and ML-9, there was no significant decrease in THBS4 mRNA expression (Figure 4C). These data suggest that, not only PDGFR $\beta$, but also IP3R and STIM1 participate in the post-translational modification and secretion of THBS4. 
A
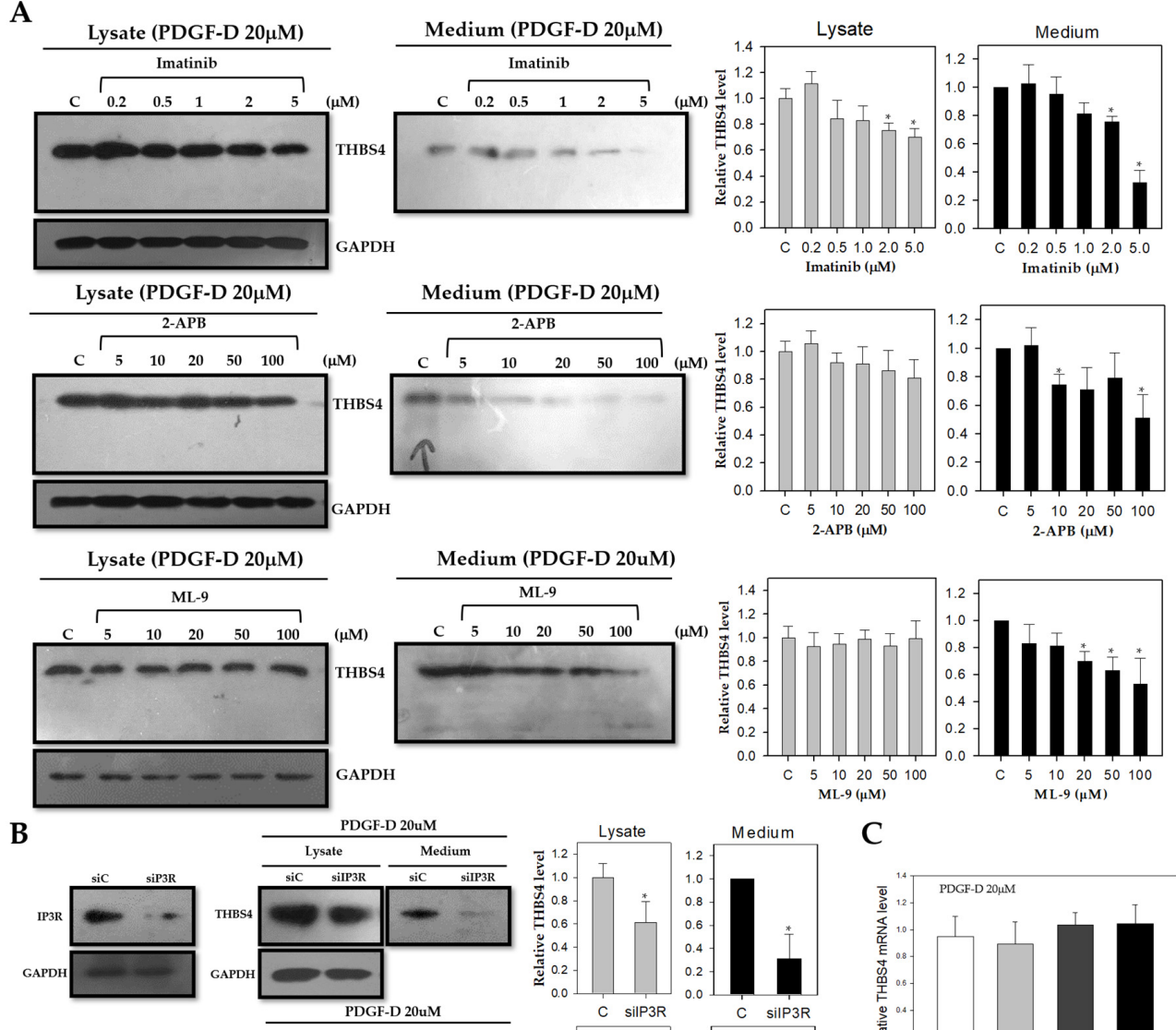

C
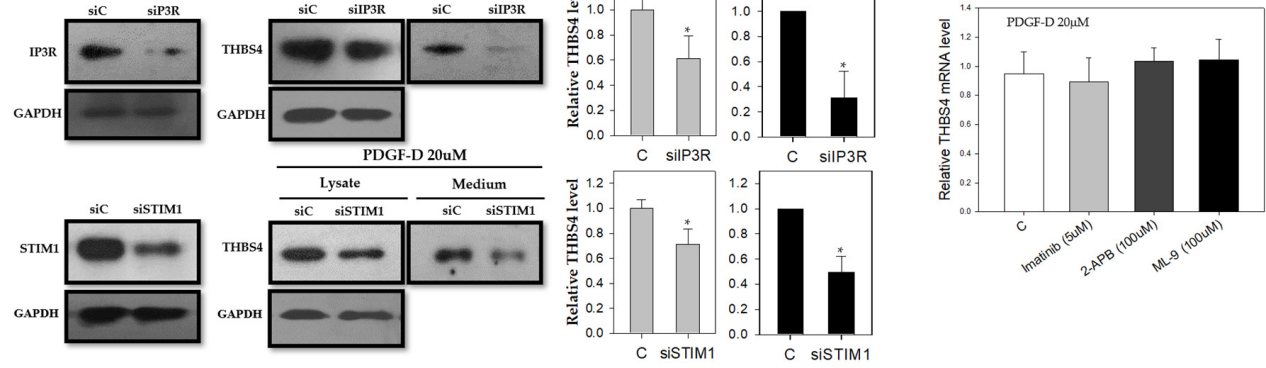

Figure 4. Effect of PDGF-D stimulation of THBS4 after blockage of PDGFR $\beta$, IP3R, and STIM1. (A) Western blot with anti-THBS4 antibody in whole cell lysate (left panel) or cultured medium (right panel) of DLD-1 cells cultured with PDGF-D $(20 \mu \mathrm{M})$ for $8 \mathrm{~h}$ in the presence of imatinib $(0,0.2$, $0.5,1,2$, and $5 \mu \mathrm{M})$ for $16 \mathrm{~h}$, 2-APB $(0,5,10,20,50$, and $100 \mu \mathrm{M})$ for $16 \mathrm{~h}$, or ML-9 $(0,5,10,20,50$, and $100 \mu \mathrm{M}$ ) for $16 \mathrm{~h}$, respectively. (B) Western blot with anti-THBS4 antibody in whole cell lysate or cultured medium of DLD-1 cells transfected with siIP3R or siSTIM1 and cultured with PDGF-D (20 $\mu \mathrm{M})$ for $8 \mathrm{~h}$. (C) Relative mRNA expression levels as determined with real-time PCR for THBS4 of DLD-1 cells cultured with PDGF-D $(20 \mu \mathrm{M})$ for $8 \mathrm{~h}$ in the presence of imatinib $(5 \mu \mathrm{M})$ for $16 \mathrm{~h}$, 2-APB $(100 \mu \mathrm{M})$ for $16 \mathrm{~h}$ or ML-9 $(100 \mu \mathrm{M})$ for $16 \mathrm{~h}$, respectively. Three independent experiments were performed in duplicate. ${ }^{*} p<0.05$ when compared with the control $t$-test.

\subsection{PDGF-D Increases THBS4 through PDGFR $\beta$ and $\mathrm{Ca}^{2+}$ Signaling Proteins}

Previously, we confirmed that PDGFR $\beta$ and $\mathrm{Ca}^{2+}$ signaling proteins mediate changes in THBS4 through PDGF-D stimulation. However, to validate that TGF $\beta$ increases PDGF-D, and, ultimately, affects THBS4, we treated DLD- 1 cells with TGF $\beta$ for $0,4,8,12,16,20$, and $24 \mathrm{~h}$ and identified the expression levels of PDGF-D and THBS4. We found that, after TGF $\beta$ treatment in DLD-1 cells, the relative intensity of PDGF-D peaked at $12 \mathrm{~h}$ and gradually decreased over time, while, that of THBS4, increased from $12 \mathrm{~h}$ to $20 \mathrm{~h}$. We treated the same cells with PDGF-D for $12 \mathrm{~h}$ and found that the THBS4 relative intensity peaked at $8 \mathrm{~h}$ after PDGF-D treatment. This was consistent with the highest expression of PDGF-D at $12 \mathrm{~h}$ after TGF $\beta$ treatment (Figure 5A). Results of TGF $\beta$ treatment in the presence of the PDGFR $\beta$-inhibitor, imatinib, showed an elevated relative intensity level for PDGF-D at $12 \mathrm{~h}$ after treatment, which is similar to that of cells without the addition of imatinib. However, THBS4 levels 
remained low after the addition of PDGF-D in imatinib-treated cells, which indicates the significance of PDGFR $\beta$ on THBS4 upregulation (Figure 5B). TGF $\beta$ treatment in cells cultured with 2-APB also showed increased PDGF-D expression at $12 \mathrm{~h}$ but did not significantly alter THBS4 levels nor did the addition of PDGF-D have any significant effect on THBS4 (Figure 5C). These results provide further evidence that TGF $\beta$ increases PDGF-D and PDGF-D subsequently increases THBS4 through PDGFR $\beta$ in a sequential manner, and $\mathrm{Ca}^{2+}$ signaling proteins also function as in our proposed mechanism.

\section{A}
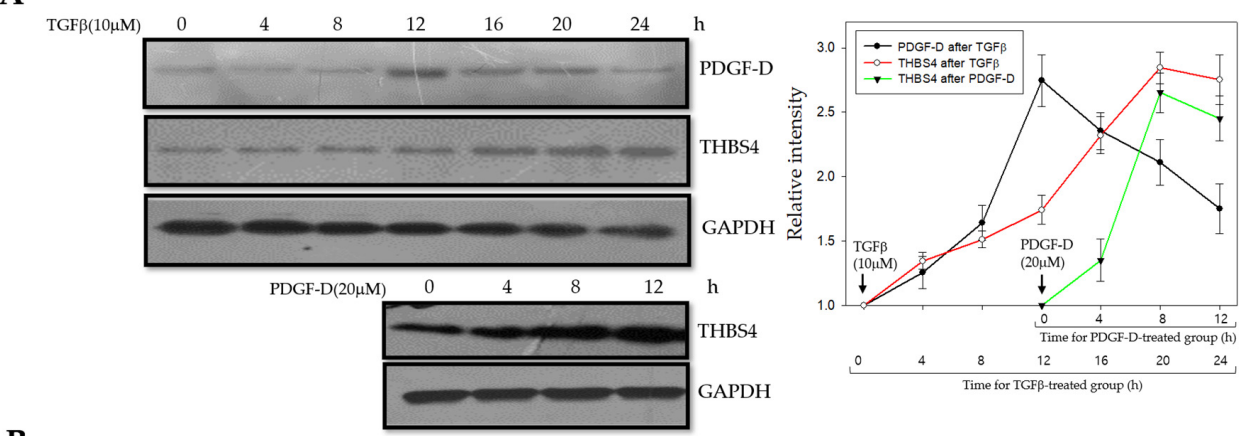

B
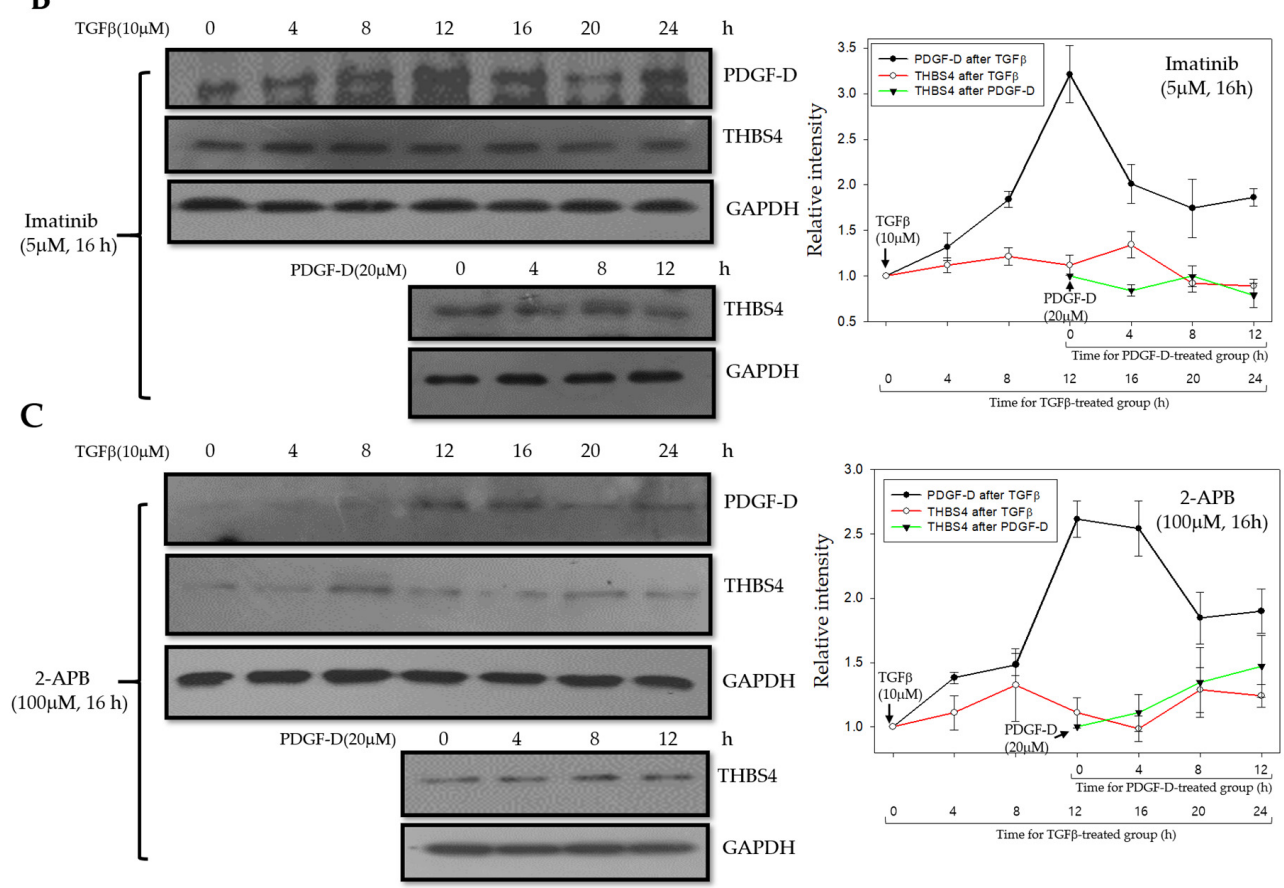

Figure 5. Effect of imatinib and 2-APB on THBS4 regulation by TGF $\beta$ and PDGF-D in a time-dependent manner. (A) Western blot with anti-PDGF-D and anti-THBS4 antibodies in the presence of TGF $\beta 10 \mu \mathrm{M}$ $(0,4,8,12,16,20$, and $24 \mathrm{~h})$ or with anti-THBS4 antibody in the presence of PDGF-D $20 \mu \mathrm{M}(0,4,8$ and $12 \mathrm{~h}$ ) in DLD-1 cells. (B) Western blot with anti-PDGF-D and anti-THBS4 antibodies in the presence of TGF $\beta 10 \mu \mathrm{M}(0,4,8,12,16,20$, and $24 \mathrm{~h})$ or with anti-THBS4 antibody in the presence of PDGF-D $20 \mu \mathrm{M}(0,4,8$, and $12 \mathrm{~h})$ in DLD-1 cells cultured with imatinib $5 \mu \mathrm{M}$ for $16 \mathrm{~h}$. (C) Western blot with anti-PDGF-D and anti-THBS4 antibodies in the presence of TGF $\beta 10 \mu \mathrm{M}(0,4,8,12,16,20$, and $24 \mathrm{~h})$ or with anti-THBS4 antibody in the presence of PDGF-D $20 \mu \mathrm{M}(0,4,8$ and $12 \mathrm{~h})$ in DLD-1 cells cultured with 2-APB $100 \mu \mathrm{M}$ for $16 \mathrm{~h}$. The graphs in the right panel represent the relative expression of PDGF-D (black line with closed circle). THBS4 (red line with open circle) in relation to exposure (time, $\mathrm{h}$ ) with TGF $\beta$ and the relative expression of THBS4 after the addition of PDGF-D (green line with closed triangle) through $12 \mathrm{~h}$. Three independent experiments were performed in duplicate. 


\subsection{Stimulation of PDGFR $\beta$ in Colon Cancer Cells Promotes Adhesion, Migration, and Proliferation of Colonic Myofibroblasts}

To investigate how THBS4 is stimulated and secreted by colon cancer cells, and whether the colon cancer cells can affect neighboring cells around it, colonic myofibroblast CCD-18co cells were cultured in the conditioned medium (CM) of DLD-1 cells or SW-48 cells stimulated with respective factors (Figure 6A,B). SW-48 cells are colorectal adenocarcinoma cells like DLD-1, but do not express THBS4 (Figure S4) [45]. Adhesion and migration assays were also performed on the CCD-18co cells. The PDGF-D-stimulated DLD-1 CM increased adhesion and migration compared to that in normal medium. However, PDGF-D-stimulated DLD-1 CM treated with imatinib while 2-APB or ML-9 did not. Conversely, the PDGF-D-stimulated SW-48 CM did not significantly increase adhesion or migration of CCD-18co cells (Figure 6A,B). This implies that THBS4 secreted by PDGF-D stimulation in DLD-1 cells might promote adhesion and migration of CCD-18co cells. Additionally, these properties were further enhanced with the inclusion of thrombin in the CM (Figure 6C-E). These results suggest that excessive stimulation of PDGFR $\beta$ in colon cancer cells may over-secrete THBS4 and promote the adhesion, migration, and proliferation of normal colon myofibroblasts.

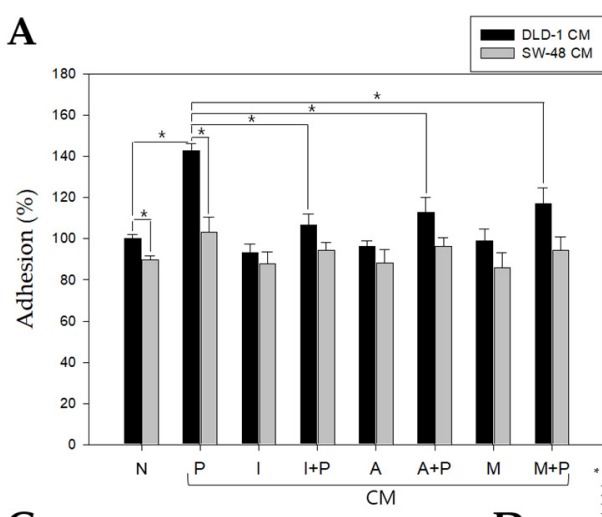

C

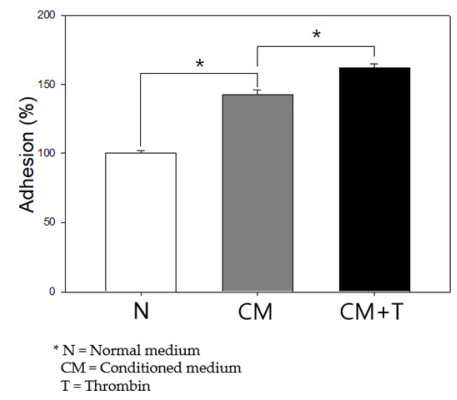

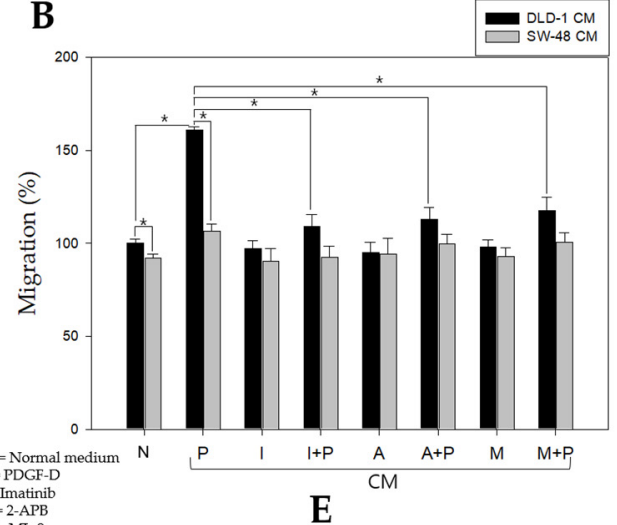

E
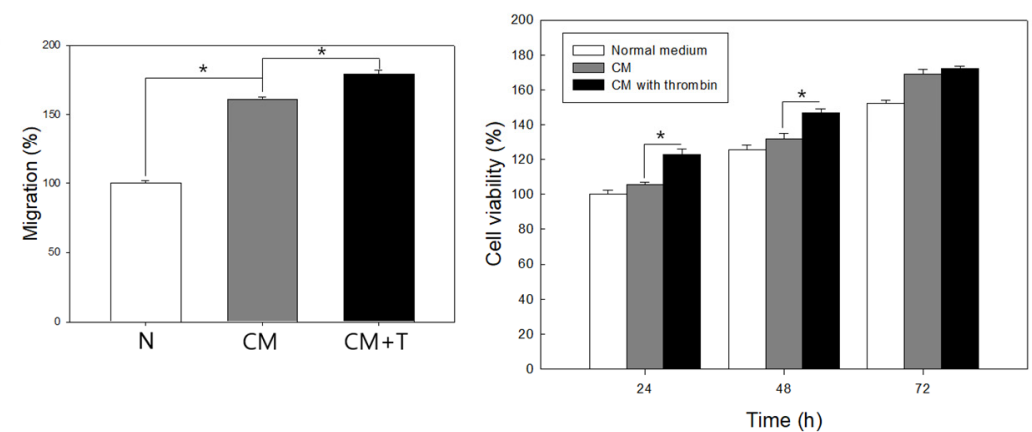

Figure 6. Effect of DLD-1 cell conditioned medium (CM) stimulated with PDGF-D and additional thrombin treatment on CCD-18co cells. (A,B) Adhesion and migration of CCD-18co cells cultured with DLD-1 CM stimulated with PDGF-D (P), imatinib (I), I + P, 2-APB (A), A + P, ML-9 (M), and M + P. DLD-1 cells were treated with imatinib 5 M, 2-APB 100 or ML-9 100 for 16 h, and then PDGF-D 20 additionally treated for $8 \mathrm{~h}$. (C,D,E) CCD-18co cells were cultured with CM or CM with thrombin $(1 \mathrm{U} / \mathrm{mL})(\mathrm{CM}+\mathrm{T})$ of DLD-1 cells stimulated with PDGF-D 20 for $8 \mathrm{~h}$ and subjected to an adhesion assay, migration assay, and an 3-(4,5-dimethylthiazol-2-yl)-2,5-diphenyl tetrazolium bromide (MTT) assay. All experiments were performed in duplicate in three independent experiments. ${ }^{*} p<0.05$, compared with normal or CM $t$-test. 


\subsection{A Proposed Novel Molecular Pathway for the Development of Colon Cancer}

Based on these results, we hypothesize: (1) TGF $\beta$ secreted by CRC cells activates TGF $\beta$ receptors in tumor cells and increases expression of PDGF-D, (2) secreted PDGF-D subsequently activates PDGFR $\beta$ to be overexpressed in tumor cells through autocrine or paracrine mechanisms. Following this, PDGFR $\beta$ activates the IP3 signaling molecule in the plasma membrane to stimulate its corresponding $\mathrm{Ca}^{2+}$ release channel, IP3R, from the ER. (3) Following the functioning of IP3R, the $\mathrm{Ca}^{2+}$ inside the ER is released into the cytoplasm, and through $\mathrm{Ca}^{2+}$ binding, the incomplete form of THBS4 is transformed into the complete THBS4 pentamer in the ECM. (4) THBS4 is secreted into the extracellular space and induces angiogenesis, adhesion, migration, and proliferation of tumor tissue, which is further promoted by thrombin. (5) Lastly, this response leads to a partial depletion of $\mathrm{Ca}^{2+}$ inside the ER, which further increases the secretion of THBS4 through STIM1, as well as intracellular $\mathrm{Ca}^{2+}$ influx into the cytoplasm (Figure 7).

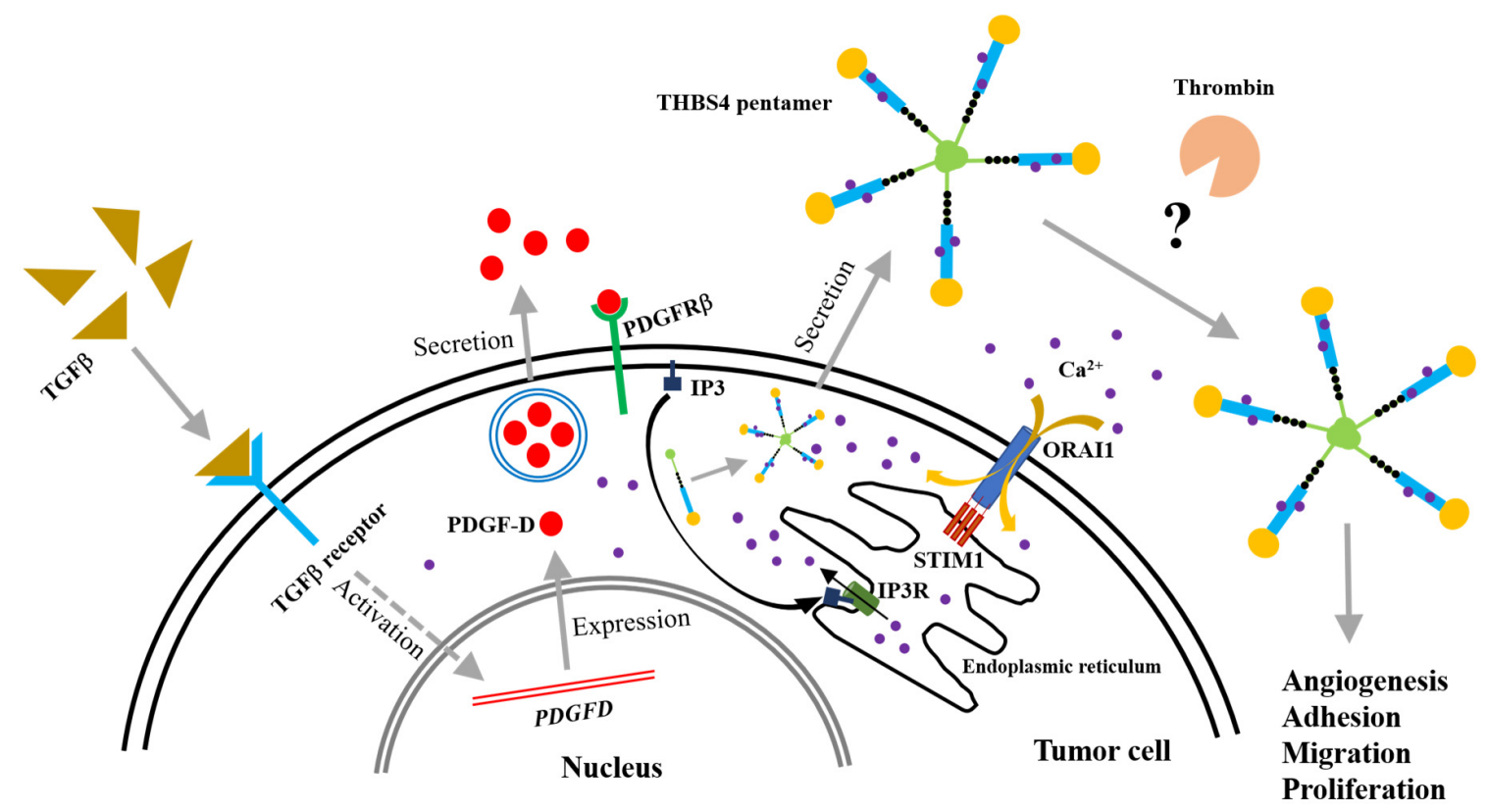

Figure 7. Model representing possible molecular pathways by which PDGFR $\beta$ and THBS4 cause the development of colorectal cancer.

\section{Discussion}

In this study, we examined the relationship among PDGFR $\beta$, THBS4, and CRC. This study showed that PDGFR $\beta$ was overexpressed and that THBS4 was significantly increased in the tumor tissue when compared to normal colon tissue in CRC patients (Figure 1). We believe that PDGFR $\beta$ and THBS4 are involved in the progression of tumors that have already formed rather than tumorigenesis.

The role of THBS4 in cancer has primarily been focused on tumor adhesion, migration, invasion, and angiogenesis [14-16,31,32] while the role of PDGFR $\beta$ has been extensively studied in epithelial-mesenchymal transition (EMT) and metastasis $[25,26,33,46,47]$. These two proteins have been shown to be associated with TGF $\beta$ in cancer. However, specific mechanisms remain undiscovered, and several studies indicate that TGF $\beta$ inhibits early-stage tumors by inducing cancer cell apoptosis and cell cycle arrest and by promoting cell differentiation. However, TGF $\beta$ has been found to promote tumor growth and metastasis at a later stage by activating specific pathways in vascular cell types and by increasing angiogenesis $[32,48]$. Due to compelling evidence presented in previously published work enforcing our original hypothesis, we sought to identify the roles of PDGFR $\beta$ and THBS4 using TGF $\beta$. TGF $\beta$ treatment increased PDGF-D in DLD- 1 cells while TGF $\beta$ and PDGF-D increased protein levels and secretion of THBS4 (Figures 2 and 3). PDGF-D functions by binding to PDGFR $\beta$ [27,49] 
and promoting cell growth, which increases the aggressiveness of other cancer cells, angiogenesis, and EMT of CRC [29]. In our study, TGF $\beta$ increased mRNA levels of PDGF-D (Figure 2B and Figure S2B), but PDGF-D did not increase the mRNA levels of THBS4 (Figure 3B). This implies that PDGFR $\beta$ activation by PDGF-D occurs upstream of THBS4 secretion and that TGF $\beta$ is located upstream of PDGFR $\beta$ activation, which suggests that both TGF $\beta$ and PDGFR $\beta$ are involved in stabilization through post-translational modification of THBS4. However, these responses were reduced by blocking PDGFR $\beta$, IP3R, and STIM1 (Figure 4A,B), which suggests that IP3R and STIM1 may also be involved in the stabilization of THBS4. Considering the possibility that the increase in THBS4 was not increased by PDGF-D, but by each specific inhibitor and siRNAs, we checked the THBS4 levels without PDGF-D stimulation. There was no significant change in THBS4 without PDGF-D stimulation (Figure S3). Additionally, the inhibitors and siRNAs did not significantly alter the proliferation of DLD-1 cells without PDGF-D stimulation, which indicates that the THBS4 decrease was not due to cell death (Figure S5 and S6). Time-dependent experiments supplemented this hypothesis. After TGF $\beta$ treatment, PDGF-D increased first, which was followed by THBS4. Based on this, PDGF-D treatment ultimately increased THBS4. Additionally, TGF $\beta$ treatment increased PDGF-D but did not increase THBS4 in cells with imatinib and 2-APB in a time-dependent manner (Figure 5). Since imatinib blocks PDGFR $\beta$ and PDGF-D expression by TGF $\beta$ does not affect the regulation of THBS4, blocking IP3R with 2-APB affects THBS4 secretion after PDGFR $\beta$ activation. We describe in this scenario that stability of THBS4 by the PDGFR $\beta$ pathway based off of the evidence provided indicated increased protein and secretion levels, despite no significant changes in mRNA. However, other post-translational modifications, such as protein folding, may be involved in this pathway, which should be examined further.

Abnormal $\mathrm{Ca}^{2+}$ signaling by altered channel expression or activation contributes to carcinogenesis and promotes tumor development [50]. The $\mathrm{Ca}^{2+}$ concentration in the cytoplasm remains very low but can be temporarily increased by IP3R and store-operated $\mathrm{Ca}^{2+}$ entry (SOCE) [51,52]. The collapse of normal $\mathrm{Ca}^{2+}$ signaling contributes to the development of malignant phenotypes. Tumors reconstitute their $\mathrm{Ca}^{2+}$ signaling networks to proliferate at high rates, increase cell motility and invasion, manipulate the immune response, or cause angiogenesis [53-58]. Our data demonstrate the possibility that excessive PDGF-D levels may disrupt the homeostasis of $\mathrm{Ca}^{2+}$ signaling and promote the excessive secretion of THBS4. This phenomenon might be caused by the $\mathrm{Ca}^{2+}$-binding domain of THBS4 [6-9], and secreted THBS4 is known to regulate the tumor microenvironment through adhesion, migration, and attachment functions of ECM proteins [10,16]. We found that the conditioned medium of PDGF-D-stimulated DLD-1 cells increased adhesion, migration, and proliferation of normal colon myofibroblasts. This became more apparent through SW-48 cells that do not express THBS4 [45] and various CM that used imatinib, 2-APB, and ML-9 together (Figure 6). These results indicate that PDGF-D affects myofibroblasts by altering the microenvironment around the tumor with THBS4, which might be induced to convert to cancer-associated fibroblasts. This response was further increased when the $\mathrm{CM}$ contained thrombin (Figure 6C-E), as it may have directly affected myofibroblasts. However, there remains the possibility of thrombin promoting the action of THBS4, and, additionally, one of the members of the THBS family, THBS1, has also been shown to be sensitive to thrombin in platelets secreted and cleaved by thrombin [59-61]. While the results presented in this paper are promising, the role of thrombin in THBS4 remains to be established and needs to be explored in future studies.

\section{Materials and Methods}

\subsection{Cell Culture and Treatments}

Human colon cancer epithelial cells DLD-1 (Male, Dukes's stage C), HCT116 (Male, Dukes's stage D), and colonic myofibroblast CCD-18co cells (Female) were obtained from the Korean Cell Line Bank, and SW48 (Female, Dukes's stage C) was purchased from ATCC. DLD-1 and HCT116 cells were cultured in RPMI-1640 (Gibco, Carlsbad, CA, USA) and CCD-18co and SW48 were cultured in Dulbecco's Modified Eagle Medium (DMEM) (Gibco, Carlsbad, CA, USA) with L-glutamine ( $300 \mathrm{mg} / \mathrm{L}$ ) 
supplemented with $10 \%$ fetal bovine serum (Gibco), penicillin $(100 \mathrm{U} / \mathrm{mL})$, and streptomycin $(100 \mu \mathrm{M})$. DLD-1 cells were treated with TGF $\beta$ (R\&D systems, Minneapolis, MN, USA), PDGF-D (R\&D systems), imatinib (Tocris Bioscience, Bristol, UK), 2-APB (Tocris), and ML-9 (Sigma Aldrich, St. Louis, MO, USA) for 8 or $16 \mathrm{~h}$. The conditioned medium was obtained from the supernatant of cells collected $8 \mathrm{~h}$ after PDGF-D stimulation, and treated with fresh medium in a 1:1 ratio to CCD-18co cells. To prevent mycoplasma contamination, Plasmocin ${ }^{\mathrm{TM}}$ (Invitrogen, San Diego, CA, USA, ant-mpp) was added to the medium.

\subsection{Human Tissue}

Surgically resected normal and tumor tissues from 12 sigmoid or rectal cancer patients were obtained from Wonkwang University Hospital (Table 1). Informed consent was obtained from all patients. The research approval number is WKIRB-201911-BR-086.

Table 1. Information on 12 colorectal cancer (CRC) patients.

\begin{tabular}{ccc}
\hline Sex & Age & Location \\
\hline Male & 79 & Rectum \\
Male & 57 & Rectum \\
Male & 88 & Sigmoid \\
Male & 65 & Sigmoid \\
Male & 35 & Rectum \\
Male & 82 & Rectosigmoid \\
\hline Male & 46 & Descending \\
& colon \\
\hline Female & 77 & Sigmoid \\
\hline Female & 41 & Sigmoid \\
\hline Female & 76 & Rectum \\
\hline Female & 59 & Rectosigmoid \\
\hline Female & 79 & Rectum \\
\hline
\end{tabular}

\subsection{Transfection}

DLD-1 cells were transfected with IP3R siRNA 10nM (sc-42475, Santa Cruz Biotechnology, Santa Cruz, Dallas, TX, USA) or STIM1 siRNA $10 \mathrm{nM}$ (sc-76589) along with control siRNA (sc-37007). IP3R and STIM1 siRNA are pools of three target-specific 19-25 nt siRNAs. The transfection reagent (sc-29528) was used per the manufacturer's protocol. After $24 \mathrm{~h}$ of transfection, the medium was replaced by fresh medium. After $24 \mathrm{~h}$, the cells were incubated with PDGF-D for $8 \mathrm{~h}$.

\subsection{Western Blot Analysis}

Cells were lysed in a protein extraction solution (Intron, Seongnam, South Korea). After centrifugation, the samples were boiled at $95^{\circ} \mathrm{C}$ for $10 \mathrm{~min}$, and $50 \mu \mathrm{g}$ protein of each lysate was subjected to electrophoresis on $10 \%$ sodium dodecyl sulfate polyacrylamide gels. All samples were electroblotted on polyvinylidene fluoride membranes (Merck Millipore, Burlington, MA, USA) and, after blocking, the blots were incubated with appropriate rabbit anti-THBS4 (Santa Cruz Biotechnology, sc-390734), rabbit anti-PDGFR $\beta$ (Abcam, Cambridge, MA, USA, ab32570), mouse anti-phosphorylated PDGFR $\beta$ (Santa Cruz Biotechnology, sc-365464), rabbit anti-PDGF-D (Abcam, Cambridge, MA, USA, ab234666), mouse anti-IP3R (Santa Cruz Biotechnology, sc-271197), and rabbit anti-STIM1 (Cell Signaling Technology, Danvers, MA, USA, 5668S) antibodies in TBS-T (TBS-0.05\% Tween 20) for $90 \mathrm{~min}$, which was followed by washing three times with TBS-T for $15 \mathrm{~min}$ each, and incubation with horseradish peroxidase-conjugated anti-mouse or rabbit immunoglobulin $\mathrm{G}$ antibodies for $1 \mathrm{~h}$. After further washing, the blots were incubated for 3 min with Western blotting HRP-substrate (Merck Millipore), 
and chemiluminescence was detected after exposure of the filters to ECL-Western blot films for $10 \mathrm{~s}$ to 10 min. Original Western blots are shown on Figures S7-S14.

\subsection{Trichloroacetic Acid Precipitation}

Supernatants were precipitated with $10 \%$ trichloroacetic acid (TCA) and incubated on ice for $1 \mathrm{~h}$ before centrifugation at $18,000 \times g$ for $30 \mathrm{~min}$. The protein pellets were washed three times with cold acetone and centrifuged at $18,000 \times g$ for $5 \mathrm{~min}$. TCA-precipitated proteins were separated using Western blot analysis.

\subsection{Immunofluorescence}

After surgical resection of tissues, the tissues were fixed immediately with $4 \%$ paraformaldehyde for $4 \mathrm{~h}$. After washing three times with phosphate-buffered saline (PBS), the tissues were fixed with acetone for $15 \mathrm{~min}$. After washing three times with PBS, the tissues were dehydrated in $30 \%$ sucrose until it subsided. The tissues were then frozen with Frozen Section Compound (Leica Biosystems Richmond Inc, Richmond, IL, USA). The cryostat-sectioned human colon tissues were blocked at room temperature for $1 \mathrm{~h}$ in diluted egg white with TBS (1 egg white: $100 \mathrm{~mL}$ TBS) to block endogenous biotin and $1 \mathrm{~h}$ in $4 \%$ skimmed milk containing $0.1 \%$ Triton $\mathrm{X}-100$. Primary antibodies against the following antigens were applied overnight: anti-THBS4 (mouse, 1:50, Santa Cruz Biotechnology, Santa Cruz, CA, USA, sc-390734) and anti-PDGFR (rabbit, 1:100, Abcam, Cambridge, MA, USA, ab32570). The tissues were incubated with biotin for $1 \mathrm{~h}$ at room temperature and then with Alexa488-conjugated antibodies or Alexa594-conjugated streptavidins for $2 \mathrm{~h}$ at room temperature. Images were collected using confocal microscopy and the Fluoview FV10-ASW 3.1 Viewer software (Olympus, Tokyo, Japan) with an Olympus FV1000 confocal laser scanning microscope (Olympus).

\subsection{Migration Assay}

CCD-18co cells were trypsinized, resuspended in serum-free DMEM, and plated into the upper chambers of the Boyden chamber assay with PDGF-D-stimulated DLD-1 cell-conditioned medium. The lower chambers were plated with $10 \%$ fetal bovine serum (FBS). Cells were then incubated at $37^{\circ} \mathrm{C}$ for $4 \mathrm{~h}$ and the lower surface of polycarbonate membranes was stained with $0.1 \%$ crystal violet. Lastly, the number of cells was quantified.

\subsection{Proliferation Assay}

The proliferation assay was performed using 3-(4, 5-dimethylthiazol-2-yl)-2,5-diphenyltetrazolium bromide (MTT) (Sigma Aldrich, St. Louis, MO, USA). CCD-18co cells were cultured for 24, 48, and $72 \mathrm{~h}$ with $10 \%$ FBS, washed with PBS, and incubated for $4 \mathrm{~h}$ at $37^{\circ} \mathrm{C}$ with $0.5 \mathrm{mg} / \mathrm{mL}$ MTT solution. After incubation, the absorbance was measured with a microplate reader (ReTiSoft Inc., Mississauga, ON, Canada) at a wavelength of $570 \mathrm{~nm}$ to determine cell proliferation.

\subsection{Adhesion Assay}

The adhesion assay was performed using collagen I-coated plates. The cells were suspended in serum-free medium, transferred to coated wells, and incubated at $37{ }^{\circ} \mathrm{C}$ in $5 \% \mathrm{CO}_{2}$ for $2 \mathrm{~h}$. After incubation, the plates were washed with PBS to remove unbound cells. The cells were then stained with $0.1 \%$ crystal violet, and the absorbance was measured with a microplate reader (ReTiSoft Inc.) at a wavelength of $570 \mathrm{~nm}$ to determine the number of cells attached to the surface.

\subsection{Quantitative Reverse Transcription-PCR ( $q R T-P C R)$}

RNA was isolated from cells with Trizol (Invitrogen, Carlsbad, CA, USA), according to the manufacturer's instructions and amplified by PCR using the POWER SYBR ${ }^{\circledR}$ Green PCR Master Mix (Thermo Fisher Scientific, Waltham, MA, USA), according to the manufacturer's instructions. 
Each sample was tested in triplicate. Glyceraldehyde 3-phosphate dehydrogenase (GAPDH) was used as an endogenous control. Primer sequences are shown in Table 2.

Table 2. The sequence of primers.

\begin{tabular}{|c|c|}
\hline Gene & Sequence $\left(5^{\prime} \rightarrow 3^{\prime}\right)$ \\
\hline \multirow{3}{*}{ PDGF-A } & Forward: \\
\hline & CGTAGGGAGTGAGGATTCTTTG \\
\hline & Reverse: AAATGACCGTCCTGGTCTTG \\
\hline \multirow{2}{*}{ PDGF-B } & Forward: CTCGATCCGCTCCTTTGATG \\
\hline & Reverse: AGGAAGTTGGCGTTGGTG \\
\hline \multirow{2}{*}{ PDGF-C } & Forward: GTCAATGTGTCCCAAGCAAAG \\
\hline & Reverse: CCACGTCGGTGAGTGATTT \\
\hline \multirow{2}{*}{ PDGF-D } & Forward: GAAATTGTGGCTGTGGAACTG \\
\hline & Reverse: GGCCAGGCTCAAACTGTAATA \\
\hline \multirow{2}{*}{ PDGFR } & Forward: GTGACAGACTACCTCTTTGG \\
\hline & Reverse: СТАСАTСТСССАGTGTСТСС \\
\hline \multirow{2}{*}{ THBS4 } & Forward: GTTCAGCCACCATCTTCGGTC \\
\hline & Reverse: GCACCTTCCCATCGTTCTTCAG \\
\hline \multirow{3}{*}{ GAPDH } & Forward: CCACATCGCTCAGACACCATG \\
\hline & Reverse: \\
\hline & GTCAATGAAGGGGTCATTGATGGC \\
\hline
\end{tabular}

\subsection{Statistical Analysis}

All blots were analyzed using ImageJ software 1.53. All statistical analyses were performed using Student's t-tests with ${ }^{*} p<0.5$ considered as significant using 10.0 SigmaPlot software (Systat Software, Inc., San Jose, CA, USA). The data are expressed as mean \pm standard error (SE).

\section{Conclusions}

Our data suggest that the secretion pathway of THBS4 by activating PDGFR $\beta$ following TGF $\beta$ in CRC involves $\mathrm{Ca}^{2+}$ signaling proteins such as IP3R and STIM1 in this pathway (Figure 7). Since THBS4 may increase tumor invasion by regulating the microenvironment through this pathway, which determines the function of THBS4 may significantly contribute to understanding the development of CRC in future research and lead to potential pharmacological agents in hopes of attenuating cancer development.

Supplementary Materials: The following are available online at http://www.mdpi.com/2072-6694/12/9/2533/s1. Figure S1. Co-immunofluorescence and immunoblots for THBS4 and PDGFR $\beta$ in normal and tumor tissues of colon cancer patients, Figure S2. Effect of TGF $\beta$ on mRNA levels of THBS4, PDGFR $\beta$, and PDGFR $\beta$ ligands, Figure S3. Protein levels of THBS4 without PDGF-D stimulation, Figure S4. Basal THBS4 levels in DLD-1, SW40, and HCT-116 cells, Figure S5. Cell proliferation of DLD-1 cells after treatment with imatinib, 2-APB, and ML-9, Figure S6. Cell proliferation of DLD-1 cells after siIP3R and siSTIM1 transfection, Figure S7. Original Western Blots of Figure 1, Figure S8. Original Western Blots of Figure 2, Figure S9. Original Western Blots of Figure 3, Figure S10. Original Western Blots of Figure 4A, Figure S11. Original Western Blots of Figure 4B, Figure S12. Original Western Blots of Figure 5A, Figure S13. Original Western Blots of Figure 5B, Figure S14. Original Western Blots of Figure 5C.

Author Contributions: Conceptualization, M.S.K. and M.Y.L.; Data curation, M.S.K. and M.Y.L.; Funding acquisition, M.S.K. and M.Y.L.; Investigation, M.S.K., H.S.C., M.W., J.M. and E.J.K.; Project administration, M.S.K. and M.Y.L.; Resources, W.C.P. and K.Y.K.; Supervision, M.Y.L.; Validation, M.S.K., S.E.H., Y.S.K., S.R., H.-S.R., A.B., S.C.C. and M.Y.L.; Visualization, M.S.K. and M.Y.L.; Writing-original draft, M.S.K.; Writing-review \& editing, S.E.H., Y.S.K., S.R., A.B., L.W. and M.Y.L. All authors have read and agreed to the published version of the manuscript.

Funding: The Basic Science Research Program through the National Research Foundation (NRF) of Korea funded by the Ministry of Education (No. 2019-0159) supported this research.

Conflicts of Interest: The authors declare no conflict of interest. The funders had no role in the design of the study; in the collection, analyses, or interpretation of data; in the writing of the manuscript, or in the decision to publish the results 


\section{References}

1. De Rosa, M.; Pace, U.; Rega, D.; Costabile, V.; Duraturo, F.; Izzo, P.; Delrio, P. Genetics, diagnosis and management of colorectal cancer (Review). Oncol. Rep. 2015, 34, 1087-1096. [CrossRef] [PubMed]

2. Castells, M.; Thibault, B.; Mery, E.; Golzio, M.; Pasquet, M.; Hennebelle, I.; Bourin, P.; Mirshahi, M.; Delord, J.P.; Querleu, D. Ovarian ascites-derived Hospicells promote angiogenesis via activation of macrophages. Cancer Lett. 2012, 326, 59-68. [CrossRef]

3. Guo, S.; Deng, C.-X. Effect of stromal cells in tumor microenvironment on metastasis initiation. Int. J. Biol. Sci. 2018, 14, 2083. [CrossRef] [PubMed]

4. Castells, M.; Thibault, B.; Delord, J.P.; Couderc, B. Implication of tumor microenvironment in chemoresistance: Tumor-associated stromal cells protect tumor cells from cell death. Int. J. Mol. Sci. 2012, 13, 9545-9571. [CrossRef] [PubMed]

5. Meads, M.B.; Gatenby, R.A.; Dalton, W.S. Environment-mediated drug resistance: A major contributor to minimal residual disease. Nat. Rev. Cancer 2009, 9, 665. [CrossRef] [PubMed]

6. Adams, J.C. Thrombospondins: Multifunctional regulators of cell interactions. Annu. Rev. Cell Dev. Biol. 2001, 17, 25-51. [CrossRef] [PubMed]

7. Adams, J.C.; Lawler, J. The thrombospondins. Int. J. Biochem. Cell Biol. 2004, 36, 961-968. [CrossRef]

8. Bornstein, P. Thrombospondins as matricellular modulators of cell function. J. Clin. Investig. 2001, 107, 929-934. [CrossRef]

9. Carlson, C.B.; Lawler, J.; Mosher, D.F. Structures of thrombospondins. Cell. Mol. Life Sci. CMLS 2008, 65, 672-686. [CrossRef]

10. Narouz-Ott, L.; Maurer, P.; Nitsche, D.P.; Smyth, N.; Paulsson, M. Thrombospondin-4 binds specifically to both collagenous and non-collagenous extracellular matrix proteins via its C-terminal domains. J. Biol. Chem. 2000, 275, 37110-37117. [CrossRef]

11. Adams, J.C. Functions of the conserved thrombospondin carboxy-terminal cassette in cell-extracellular matrix interactions and signaling. Int. J. Biochem. Cell Biol. 2004, 36, 1102-1114. [CrossRef] [PubMed]

12. Arber, S.; Caroni, P. Thrombospondin-4, an extracellular matrix protein expressed in the developing and adult nervous system promotes neurite outgrowth. J. Cell Biol. 1995, 131, 1083-1094. [CrossRef] [PubMed]

13. Stenina, O.I.; Desai, S.Y.; Krukovets, I.; Kight, K.; Janigro, D.; Topol, E.J.; Plow, E.F. Thrombospondin-4 and its variants: Expression and differential effects on endothelial cells. Circulation 2003, 108, 1514-1519. [CrossRef] [PubMed]

14. Forster, S.; Gretschel, S.; Jons, T.; Yashiro, M.; Kemmner, W. THBS4, a novel stromal molecule of diffuse-type gastric adenocarcinomas, identified by transcriptome-wide expression profiling. Mod. Pathol. An Off. J. United States Can. Acad. Pathol. Inc. 2011, 24, 1390-1403. [CrossRef] [PubMed]

15. Liu, J.; Cheng, G.; Yang, H.; Deng, X.; Qin, C.; Hua, L.; Yin, C. Reciprocal regulation of long noncoding RNAs THBS4003 and THBS4 control migration and invasion in prostate cancer cell lines. Mol. Med. Rep. 2016, 14, 1451-1458. [CrossRef]

16. McCart Reed, A.E.; Song, S.; Kutasovic, J.R.; Reid, L.E.; Valle, J.M.; Vargas, A.C.; Smart, C.E.; Simpson, P.T. Thrombospondin-4 expression is activated during the stromal response to invasive breast cancer. Virchows Arch. An Int. J. Pathol. 2013, 463, 535-545. [CrossRef]

17. Lee, J.; Lee, W.K.; Seol, M.-Y.; Lee, S.G.; Kim, D.; Kim, H.; Park, J.; Jung, S.G.; Chung, W.Y.; Lee, E.J. Coupling of LETM1 up-regulation with oxidative phosphorylation and platelet-derived growth factor receptor signaling via YAP1 transactivation. Oncotarget 2016, 7, 66728. [CrossRef]

18. Heldin, C.H.; Westermark, B. Mechanism of action and in vivo role of platelet-derived growth factor. Physiol. Rev. 1999, 79, 1283-1316. [CrossRef]

19. Ostman, A.; Heldin, C.H. PDGF receptors as targets in tumor treatment. Adv. Cancer Res. 2007, 97, $247-274$. [CrossRef]

20. Hwang, R.F.; Yokoi, K.; Bucana, C.D.; Tsan, R.; Killion, J.J.; Evans, D.B.; Fidler, I.J. Inhibition of platelet-derived growth factor receptor phosphorylation by STI571 (Gleevec) reduces growth and metastasis of human pancreatic carcinoma in an orthotopic nude mouse model. Clin. Cancer Res. An Off. J. Am. Assoc. Cancer Res. 2003, 9, 6534-6544. 
21. Maass, T.; Thieringer, F.R.; Mann, A.; Longerich, T.; Schirmacher, P.; Strand, D.; Hansen, T.; Galle, P.R.; Teufel, A.; Kanzler, S. Liver specific overexpression of platelet-derived growth factor-B accelerates liver cancer development in chemically induced liver carcinogenesis. Int. J. Cancer 2011, 128, 1259-1268. [CrossRef] [PubMed]

22. Seymour, L.; Bezwoda, W.R. Positive immunostaining for platelet derived growth factor (PDGF) is an adverse prognostic factor in patients with advanced breast cancer. Breast Cancer Res. Treat. 1994, 32, 229-233. [CrossRef] [PubMed]

23. Lindmark, G.; Sundberg, C.; Glimelius, B.; Pahlman, L.; Rubin, K.; Gerdin, B. Stromal expression of platelet-derived growth factor beta-receptor and platelet-derived growth factor B-chain in colorectal cancer. Lab. Investig. A J. Tech. Methods Pathol. 1993, 69, 682-689.

24. Sundberg, C.; Ljungstrom, M.; Lindmark, G.; Gerdin, B.; Rubin, K. Microvascular pericytes express platelet-derived growth factor-beta receptors in human healing wounds and colorectal adenocarcinoma. Am. J. Pathol. 1993, 143, 1377-1388.

25. Wehler, T.C.; Frerichs, K.; Graf, C.; Drescher, D.; Schimanski, K.; Biesterfeld, S.; Berger, M.R.; Kanzler, S.; Junginger, T.; Galle, P.R.; et al. PDGFRalpha/beta expression correlates with the metastatic behavior of human colorectal cancer: A possible rationale for a molecular targeting strategy. Oncol. Rep. 2008, 19, 697-704.

26. Steller, E.J.; Ritsma, L.; Raats, D.A.; Hoogwater, F.J.; Emmink, B.L.; Govaert, K.M.; Laoukili, J.; Rinkes, I.H.; van Rheenen, J.; Kranenburg, O. The death receptor CD95 activates the cofilin pathway to stimulate tumour cell invasion. EMBO Rep. 2011, 12, 931-937. [CrossRef]

27. Andrae, J.; Gallini, R.; Betsholtz, C. Role of platelet-derived growth factors in physiology and medicine. Genes Dev. 2008, 22, 1276-1312. [CrossRef]

28. Fantauzzo, K.A.; Soriano, P. PDGFRbeta regulates craniofacial development through homodimers and functional heterodimers with PDGFRalpha. Genes Dev. 2016, 30, 2443-2458. [CrossRef]

29. Chen, J.; Yuan, W.; Wu, L.; Tang, Q.; Xia, Q.; Ji, J.; Liu, Z.; Ma, Z.; Zhou, Z.; Cheng, Y.; et al. PDGF-D promotes cell growth, aggressiveness, angiogenesis and EMT transformation of colorectal cancer by activation of Notch1/Twist1 pathway. Oncotarget 2017, 8, 9961-9973. [CrossRef]

30. Jiang, B.; Chen, J.; Yuan, W.; Ji, J.; Liu, Z.; Wu, L.; Tang, Q.; Shu, X. Platelet-derived growth factor-D promotes colorectal cancer cell migration, invasion and proliferation by regulating Notch1 and matrix metalloproteinase-9. Oncol. Lett. 2018, 15, 1573-1579. [CrossRef]

31. Muppala, S.; Frolova, E.; Xiao, R.; Krukovets, I.; Yoon, S.; Hoppe, G.; Vasanji, A.; Plow, E.; Stenina-Adognravi, O. Proangiogenic properties of Thrombospondin-4. Arterioscler. Thromb. Vasc. Biol. 2015, 35, 1975-1986. [CrossRef] [PubMed]

32. Muppala, S.; Xiao, R.; Krukovets, I.; Verbovetsky, D.; Yendamuri, R.; Habib, N.; Raman, P.; Plow, E.; Stenina-Adognravi, O. Thrombospondin-4 mediates TGF-beta-induced angiogenesis. Oncogene 2017, 36, 5189-5198. [CrossRef] [PubMed]

33. Steller, E.J.; Raats, D.A.; Koster, J.; Rutten, B.; Govaert, K.M.; Emmink, B.L.; Snoeren, N.; van Hooff, S.R.; Holstege, F.C.; Maas, C.; et al. PDGFRB promotes liver metastasis formation of mesenchymal-like colorectal tumor cells. Neoplasia 2013, 15, 204-217. [CrossRef] [PubMed]

34. Anz, D.; Mueller, W.; Golic, M.; Kunz, W.G.; Rapp, M.; Koelzer, V.H.; Ellermeier, J.; Ellwart, J.W.; Schnurr, M.; Bourquin, C.; et al. CD103 is a hallmark of tumor-infiltrating regulatory T cells. Int. J. Cancer 2011, 129, 2417-2426. [CrossRef] [PubMed]

35. Lebrun, J.J. The dual role of TGFbeta in human cancer: From tumor suppression to cancer metastasis. ISRN Mol. Biol. 2012, 2012, 381428. [CrossRef] [PubMed]

36. Tian, J.; Al-Odaini, A.A.; Wang, Y.; Korah, J.; Dai, M.; Xiao, L.; Ali, S.; Lebrun, J.J. KiSS1 gene as a novel mediator of TGFbeta-mediated cell invasion in triple negative breast cancer. Cell. Signal. 2018, 42, 1-10. [CrossRef] [PubMed]

37. Bornfeldt, K.E.; Raines, E.W.; Graves, L.M.; Skinner, M.P.; Krebs, E.G.; Ross, R. Platelet-derived growth factor. Distinct signal transduction pathways associated with migration versus proliferation. Ann. N. Y. Acad. Sci. 1995, 766, 416-430. [CrossRef]

38. Heldman, A.W.; Kandzari, D.E.; Tucker, R.W.; Crawford, L.E.; Fearon, E.R.; Koblan, K.S.; Goldschmidt-Clermont, P.J. EJ-Ras inhibits phospholipase C gamma 1 but not actin polymerization induced by platelet-derived growth factor-BB via phosphatidylinositol 3-kinase. Circ. Res. 1996, 78, 312-321. [CrossRef] 
39. Pinzani, M. PDGF and signal transduction in hepatic stellate cells. Front. Biosci. 2002, 7, d1720-d1726. [CrossRef]

40. Yao, H.; Duan, M.; Yang, L.; Buch, S. Platelet-derived growth factor-BB restores human immunodeficiency virus Tat-cocaine-mediated impairment of neurogenesis: Role of TRPC1 channels. J. Neurosci. 2012, 32, 9835-9847. [CrossRef]

41. Pérez-Riesgo, E.; Gutiérrez, L.G.; Ubierna, D.; Acedo, A.; Moyer, M.P.; Núñez, L.; Villalobos, C. Transcriptomic analysis of calcium remodeling in colorectal cancer. Int. J. Mol. Sci. 2017, 18, 922. [CrossRef] [PubMed]

42. Prevarskaya, N.; Ouadid-Ahidouch, H.; Skryma, R.; Shuba, Y. Remodelling of Ca2+ transport in cancer: How it contributes to cancer hallmarks? Philos. Trans. Royal Soc. B Biol. Sci. 2014, 369, 20130097. [CrossRef] [PubMed]

43. Stewart, T.A.; Yapa, K.T.; Monteith, G.R. Altered calcium signaling in cancer cells. Biochim. Biophys. Acta (BBA)-Biomembr. 2015, 1848, 2502-2511. [CrossRef] [PubMed]

44. Bergsten, E.; Uutela, M.; Li, X.; Pietras, K.; Ostman, A.; Heldin, C.H.; Alitalo, K.; Eriksson, U. PDGF-D is a specific, protease-activated ligand for the PDGF beta-receptor. Nat. Cell Biol. 2001, 3, 512-516. [CrossRef]

45. Greco, S.A.; Chia, J.; Inglis, K.J.; Cozzi, S.J.; Ramsnes, I.; Buttenshaw, R.L.; Spring, K.J.; Boyle, G.M.; Worthley, D.L.; Leggett, B.A.; et al. Thrombospondin-4 is a putative tumour-suppressor gene in colorectal cancer that exhibits age-related methylation. BMC Cancer 2010, 10, 494. [CrossRef]

46. Thomson, S.; Petti, F.; Sujka-Kwok, I.; Epstein, D.; Haley, J.D. Kinase switching in mesenchymal-like non-small cell lung cancer lines contributes to EGFR inhibitor resistance through pathway redundancy. Clin. Exp. Metastasis 2008, 25, 843-854. [CrossRef]

47. Jechlinger, M.; Sommer, A.; Moriggl, R.; Seither, P.; Kraut, N.; Capodiecci, P.; Donovan, M.; Cordon-Cardo, C.; Beug, H.; Grunert, S. Autocrine PDGFR signaling promotes mammary cancer metastasis. J. Clin. Investig. 2006, 116, 1561-1570. [CrossRef]

48. Katz, L.H.; Li, Y.; Chen, J.S.; Munoz, N.M.; Majumdar, A.; Chen, J.; Mishra, L. Targeting TGF-beta signaling in cancer. Expert Opin. Ther. Targets 2013, 17, 743-760. [CrossRef]

49. Wang, Z.; Kong, D.; Banerjee, S.; Li, Y.; Adsay, N.V.; Abbruzzese, J.; Sarkar, F.H. Down-regulation of platelet-derived growth factor-D inhibits cell growth and angiogenesis through inactivation of Notch-1 and nuclear factor-kappaB signaling. Cancer Res. 2007, 67, 11377-11385. [CrossRef]

50. Cui, C.; Merritt, R.; Fu, L.; Pan, Z. Targeting calcium signaling in cancer therapy. Acta Pharm. Sin. B 2017, 7, 3-17. [CrossRef]

51. Csordas, G.; Varnai, P.; Golenar, T.; Roy, S.; Purkins, G.; Schneider, T.G.; Balla, T.; Hajnoczky, G. Imaging interorganelle contacts and local calcium dynamics at the ER-mitochondrial interface. Mol. Cell 2010, 39, 121-132. [CrossRef] [PubMed]

52. Varnai, P.; Balla, A.; Hunyady, L.; Balla, T. Targeted expression of the inositol 1,4,5-triphosphate receptor (IP3R) ligand-binding domain releases Ca2+ via endogenous IP3R channels. Proc. Natl. Acad. Sci. USA 2005, 102, 7859-7864. [CrossRef] [PubMed]

53. Kondratskyi, A.; Yassine, M.; Kondratska, K.; Skryma, R.; Slomianny, C.; Prevarskaya, N. Calcium-permeable ion channels in control of autophagy and cancer. Front. Physiol. 2013, 4, 272. [CrossRef] [PubMed]

54. Vandewalle, B.; Hornez, L.; Wattez, N.; Revillion, F.; Lefebvre, J. Vitamin-D3 derivatives and breast-tumor cell growth: Effect on intracellular calcium and apoptosis. Int. J. Cancer 1995, 61, 806-811. [CrossRef] [PubMed]

55. Liu, L.H.; Boivin, G.P.; Prasad, V.; Periasamy, M.; Shull, G.E. Squamous cell tumors in mice heterozygous for a null allele of Atp2a2, encoding the sarco(endo)plasmic reticulum Ca2+-ATPase isoform 2 Ca2+ pump. J. Biol. Chem. 2001, 276, 26737-26740. [CrossRef] [PubMed]

56. Roderick, H.L.; Cook, S.J. Ca2+ signalling checkpoints in cancer: Remodelling Ca2+ for cancer cell proliferation and survival. Nat. Rev. Cancer 2008, 8, 361-375. [CrossRef]

57. Karacosta, L.G.; Foster, B.A.; Azabdaftari, G.; Feliciano, D.M.; Edelman, A.M. A regulatory feedback loop between $\mathrm{Ca} 2+/$ calmodulin-dependent protein kinase kinase 2 (CaMKK2) and the androgen receptor in prostate cancer progression. J. Biol. Chem. 2012, 287, 24832-24843. [CrossRef]

58. Monteith, G.R.; Davis, F.M.; Roberts-Thomson, S.J. Calcium channels and pumps in cancer: Changes and consequences. J. Biol. Chem. 2012, 287, 31666-31673. [CrossRef]

59. Lawler, J.; Connolly, J.E.; Ferro, P.; Derick, L.H. Thrombin and chymotrypsin interactions with thrombospondin. Ann. New York Acad. Sci. 1986, 485, 273-287. [CrossRef] 
60. McLaughlin, J.N.; Mazzoni, M.R.; Cleator, J.H.; Earls, L.; Perdigoto, A.L.; Brooks, J.D.; Muldowney, J.A., 3rd; Vaughan, D.E.; Hamm, H.E. Thrombin modulates the expression of a set of genes including thrombospondin-1 in human microvascular endothelial cells. J. Biol. Chem. 2005, 280, 22172-22180. [CrossRef]

61. Baenziger, N.L.; Brodie, G.N.; Majerus, P.W. A thrombin-sensitive protein of human platelet membranes. Proc. Natl. Acad. of Sci. USA 1971, 68, 240-243. [CrossRef] [PubMed]

(C) 2020 by the authors. Licensee MDPI, Basel, Switzerland. This article is an open access article distributed under the terms and conditions of the Creative Commons Attribution (CC BY) license (http://creativecommons.org/licenses/by/4.0/). 